\title{
A policy option for valuing irrigation water in the dry areas
}

\author{
Yigezu A. Yigezu ${ }^{\mathrm{a}, *}$, Aden Aw-Hassanª, Kamil Shideed ${ }^{\mathrm{a}}$, \\ Rolf Sommer ${ }^{\mathrm{b}}$ and Tamer El-Shater ${ }^{\mathrm{a}}$
}

${ }^{a}$ Social, Economic and Policy Research Program (SEPRP), ICARDA, International Center for Agricultural Research in the Dry Areas (ICARDA), P.O. Box 950764, Amman 11195, Jordan

*Corresponding author. E-mail: y.yigezu@cgiar.org

${ }^{b}$ International Center for Tropical Agriculture (CIAT), P.O. Box 823-00621, Nairobi, Kenya

\begin{abstract}
Participants at the international conference on policies for water and food security in the dry areas, held in June 2013, agreed that, given the fast pace of depletion of groundwater, the issue of water valuation in the dry areas is no longer one of whether or not, but rather of how. Policies that have been or are perceived to have adverse effects on the cost of agricultural production or food prices in the dry areas are often not well received and have historically led to popular uprisings. As a result, despite clear evidence of misuse of irrigation water by many farmers, governments have been avoiding the idea of water pricing. This government stance is mainly based on the assumption that policies that aim at valuing water will necessarily affect farmers negatively. Using a case study from Syria and applying a simple optimization model, this paper provides empirical evidence that a policy which introduces a penalty for excessive application of irrigation water would compel farmers to adopt water saving technologies. By so doing, the policy will not only lead to groundwater conservation but also to Pareto-optimal distribution of benefits (i.e., a situation where nobody loses and at best some or all gain).
\end{abstract}

Keywords: Penalty; Sprinklers; Supplemental irrigation (SI); Surface canals; Valuation; Water conservation

\section{Introduction}

Agriculture accounts for over $70 \%$ of global freshwater withdrawals and up to $90 \%$ in some fastgrowing economies (UNWWAP, 2012). The agricultural sector is often criticized for high wastage and inefficient use of water at the point of consumption (i.e. at farm level) encouraged by no, or subsidized low, charges for water use and/or low energy tariffs for pumping (Turner et al., 2004). Excessive application of irrigation water may lead not only to depletion of groundwater but also, if water is continually pumped from groundwater sources beyond its replenishment rate, the water table can reduce all the way to a saline brackish water layer (Nova, 2006). The continuous and excessive use of such saline doi: 10.2166/wp.2014.141 
water for irrigation, without proper drainage, causes soil salinity build up which, if unchecked, could convert agricultural lands into waste land deserts that are no longer suitable for farming, with longterm negative externalities on the fauna and flora of the region.

Water charging has been a policy issue since the Dublin International Conference on Water and the Environment in 1992. There has been substantive discussion in several major irrigating countries (such as India, Pakistan, Egypt, Tunisia, Morocco, Jordan, Thailand, Viet Nam, China and Indonesia) on the introduction of 'full cost' irrigation charging (usually referring to full supply cost). However, with a few exceptions, there has been little effective implementation. In some areas, there has been a reverse trend where water charges have been abolished (in the Taiwan Province of China, in Poland and the Punjab, India), recovery rates have decreased (Eastern Europe and Pakistan) or the introduction of irrigation charges has stalled (Indonesia). A major exception to this development is the EU Water Framework Directive that aimed at full cost water pricing in all member states by 2010 (Cornish et al., 2004). Different forms of water user charges have also been applied in a few countries of the Northern Africa and West Asia region, including in Morocco, Tunisia and Jordan. Charging farmers increasing block prices for irrigation deliveries as a means of encouraging agricultural water conservation has also increasingly become common in the western states of the United States (Huffaker et al., 1998; Michelsen et al., 1999). It is, however, not clear if water pricing actually reduces water consumption.

Policies of water pricing affect and, in turn, are affected by a large number of other important issues. Although much theoretical work has been done on the economics of irrigation water pricing, there is still a considerable lack of understanding as to what impacts can be realistically expected from water pricing policies in practice (Cornish et al., 2004). Based on an extensive review of the literature, Convery (2013) advises policymakers that they can use economics to support the case for investments and policy initiatives that are likely to yield substantial net benefits (in terms of meeting certain quality or quantity objectives) and to argue against those that are not. Convery also argues that prices can be used to manage water resources efficiently. The effects of water pricing can, however, have conflicting impacts among different objectives and interest groups (Bartolini et al., 2010). Theoretical results by Huffaker et al. (1998) raised serious questions about the value of water pricing as a conservation tool and suggested that more empirical analysis was needed. This is even more the case in the developing world, as water pricing may have huge social, political and food security implications.

Using a case study from Syria and a simple optimization model, this paper attempts to demonstrate that an innovative water pricing strategy can enhance the adoption of improved irrigation techniques and lead to substantial water conservation while minimizing the likelihood of social and political unrest. Particularly, this paper provides simulation results pertaining to farmers' expected responses in terms of quantity and techniques of irrigation water application for different levels of penalty for excessive application of irrigation water (PEAIW). Taking into account the trade-offs between yields and techniques, and amounts and costs of irrigation water, this paper also aims to analyze the economic and conservation impacts of the shift from traditional supplemental irrigation (TSI) to improved supplemental irrigation (ISI). The implications of the shift from surface canals to sprinklers are also analyzed and a policy option for sustainable use of groundwater proposed. The findings of this paper are expected to be useful primarily for policymakers, while also providing good insights for farmers and extension workers alike.

The remaining sections of the paper are organized as follows: the next section describes the essence of ISI technique, its benefits and its history in Syria. Sections 3 and 4 present the methods and data used, 
respectively. The results are presented and discussed in Section 5 and, finally, some concluding remarks are presented in Section 6.

\section{Supplemental irrigation (SI): the concept and its application in Syria}

\subsection{The concept}

In the dry areas, water and not land is the most limiting resource for improved agricultural production. Maximizing water productivity, and not the yield per unit of land, is therefore a better strategy for dry farming systems. Under such conditions, more efficient water management techniques that maximize water use efficiency must be adopted (Oweis et al., 2000; Oweis \& Hachum, 2004). SI in low rainfall areas not only increases yield relative to purely rain-fed production, but also leads to optimal use of scarce water available from renewable resources, and substantially improves the productivities of water from both irrigation and rainwater when applied conjunctively (Oweis et al., 1998, 2000; Oweis \& Hachum, 2004). For example, water use efficiency measurements in West Asia and North

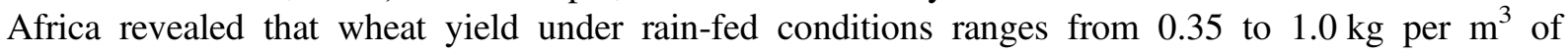
water (Oweis \& Hachum, 2009), whereas, in their study conducted in the same region, Oweis et al. (1998) showed that while yields of rainfed wheat varied with seasonal rainfall and its distribution, an addition of only limited irrigation (one third of full) significantly increased yield where near maximum yield was obtained at an application rate of two thirds of the full irrigation (Oweis et al., 1998). Ilbeyi et al. (2006) also showed that, in an ISI setting, appropriate management and optimum application of irrigation water leads to yield gains of $2.0-3.5 \mathrm{~kg}$ per cubic meter per hectare per season, relative to rain-fed wheat.

In the face of the tradeoffs between higher yields and water conservation, striking a balance between profitability and sustainability is a challenge for policymakers. Oweis \& Hachum (2009) used water production functions to model yield response to various levels of SI to assess water productivity coefficients and to identify optimum irrigation under various input-output price scenarios. Their results show that, for a given seasonal rainfall, there is a critical value for the ratio of irrigation cost to production price beyond which SI becomes less profitable than rainfed production. As a result, higher product prices and lower irrigation costs encourage the use of more water. Based on their results, Oweis \& Hachum (2009) concluded that policies supporting high wheat prices and low irrigation costs encourage maximizing yields but with low water productivity leading to farmer practices that threaten the sustainability of water resources.

\subsection{SI in Syria}

The traditional surface canal gravity irrigation (TI) system is the typical irrigation method used in Syria (WB, 2001). A study conducted in the country shows that TI leads to $10-60 \%$ water loss due only to evaporation and seepage (Abedrabboh, 2007). It also leads to over-irrigation, especially in the absence of adequate land leveling. For instance, a study conducted in the Aleppo governorate of Syria showed that, in 2007, the average water application rate for 'supplemental' irrigation of wheat was $2,658 \mathrm{~m}^{3} / \mathrm{ha}$, an amount which is $47 \%$ higher than the upper bound of the range $\left(800-1,800 \mathrm{~m}^{3} /\right.$ ha) recommended by the Syrian Ministry of Agriculture and Agrarian Reform (MAAR). 
SI is understood by most Syrian farmers as the use of irrigation in addition to rain water, regardless of the amount applied. Scientifically, SI is the application of irrigation water only when rainfall fails to provide essential moisture for stable production, and the amount and timing are scheduled to ensure that a certain amount of water is available during critical stages of crop growth (Oweis, 1997).

To avoid confusion, in this paper we make a distinction between ISI, in which the recommended water application rates are used, and TSI, where farmers use excessive irrigation above the recommended levels. Scheduling of SI is determined for each year using the water balance method. For instance, in Syria's Zones 1 and $2^{1}$, which are the study areas for this research, optimum yields were obtained with ISI of $600-1,800 \mathrm{~m}^{3} / \mathrm{ha}$ (FRMP, 1991). Hence, in this analysis, we used the upper bound of this range $\left(1,800 \mathrm{~m}^{3}\right)$ as the threshold level to distinguish between ISI and TSI.

From 1986 to 1990, the International Center for Agricultural Research in the Dry Areas (ICARDA) and the Syrian MAAR jointly implemented a project to promote and transfer ISI technologies to Syrian spring wheat farmers. The components of the ISI technology focused on irrigation scheduling: when to irrigate, how to irrigate and how much water to use (Salkini, 1992). The ISI technology package for wheat farmers in Syria was also coupled with improved wheat varieties and inorganic fertilizers. The main objectives of the project for the introduction of ISI in Syria were to reduce yield instability and increase water use efficiency. However, apart from the intended purposes, environmental benefits, such as water conservation and prevention of salinization and fertilizer leaching can be considerable, and hence became an important dimension in assessing the impacts of ISI in Syria.

\section{Methods}

The cost-benefit analysis approach has been employed to measure the farm level ex-post economic impacts of ISI. Due to the very deep wells in Syria, preliminary simulation results from the CropSyst model (Stöckle et al., 2003) revealed that salinity is and will not be a threat in the study areas in the near future, showing that the benefits of ISI in reducing soil salinity in Syria are negligible. Therefore, in this analysis, the only items included on the benefit side are the value of water conserved, and the fuel and other cost savings in the wheat farms. Direct farm level costs - including wheat yield loss (if any), cost of establishing and operating ISI and its related technologies - are included on the cost side.

Given that fuel is subsidized and there are no water user charges in Syria, using pumping cost as a measure of the value of irrigation water would be erroneous. Hence, the opportunity cost of every cubic meter of irrigation water conserved (OCW) by the shift from TSI to ISI is computed in this paper as a product of the market price of wheat and the marginal product of irrigation water $(m p w)$. The $m p w$ is derived from the following yield response function, estimated by the ordinary least squares method

\footnotetext{
${ }^{1}$ Syria is divided into five agro-climatic zones: Zone 1 represents areas with average annual rainfall exceeding $350 \mathrm{~mm}$ but with a $33 \%$ probability to be less than $300 \mathrm{~mm}$. Zone 2 comprises areas with average annual rainfall of over $250 \mathrm{~mm}$ with more than $33 \%$ probability of falling below $250 \mathrm{~mm}$, while Zone 3 refers to areas where annual average rainfall is about $250 \mathrm{~mm}$ but the probability of falling below $250 \mathrm{~mm}$ is above $50 \%$. Zones 2 and 3 have the same annual average rainfall but the probabilities of falling below the average $(250 \mathrm{~mm}$ ) differ. Areas with average rainfall of about $200 \mathrm{~mm}$ with more than a $50 \%$ chance of falling below $200 \mathrm{~mm}$ are classified under Zone 4, and those with annual rainfall of less than $200 \mathrm{~mm}$ are classified under Zone 5.
} 
using survey data. The log-linear function (a variant of the Cobb-Douglas function) is assumed to describe the production function ${ }^{2}$ of the typical Syrian wheat farms, where yield is regressed against the amount of irrigation and rain water applied along with the quantity and quality attributes of other inputs:

$$
\begin{aligned}
\ln \left(\text { Yield }_{i}\right)= & \beta_{0}+\beta_{1} * \ln \left(\text { Area }_{i}\right)+\beta_{2} * \ln \left(Q W_{i}\right)+\beta_{3} * \ln \left(N_{i}\right) \\
& +\beta_{4} * \ln \left(P_{i}\right)+\beta_{5} * \ln \left(\operatorname{Seed}_{i}\right)+\beta_{6} * \operatorname{Salin}_{i}+\beta_{7} * \operatorname{SoilT}_{i} \\
& +\beta_{8} * \operatorname{Var}_{i}+\beta_{9} * \mathrm{IM}_{i}+\beta_{10} * \ln (Y S)_{i}+\beta_{11} \ln (\text { Rainfall })_{i}+\epsilon_{i}
\end{aligned}
$$

where, Yield $_{i}=$ Yield $\left(\mathrm{kg}\right.$ per ha); Area ${ }_{i}=$ Area in ha; $Q W_{i}=$ Quantity of irrigation water $\left(\mathrm{m}^{3} / \mathrm{ha}\right)$ applied during the crop season; $N_{i}=$ Nitrogen fertilizer $(\mathrm{kg} / \mathrm{ha}) ; P_{i}=$ Phosphorous fertilizer $(\mathrm{kg} / \mathrm{ha})$; Seed $_{i}=\operatorname{seed}(\mathrm{kg} / \mathrm{ha}) ;$ Zone $_{i}=$ Zone dummy $(0=$ zone 1 and $1=$ zone 2$) ; \operatorname{Salin}_{i}=$ Soil salinity dummy $(0=$ low and $1=$ high $) ;$ SoilT $_{i}=$ Soil type dummy $(1=$ deep red and $0=$ otherwise $) ; \mathrm{Va}_{i}=$ Wheat variety dummy $(0=$ local and $1=$ improved $) ; I M_{i}=$ Irrigation Method dummy $(0=$ traditional surface canal and $1=$ sprinklers); $Y S_{i}=$ Years of schooling.

For the ex-ante analysis of the potential impacts of the shift from surface canal to sprinkler irrigation, as well as the implications of the introduction of different policy options, we used a simple optimization model based on mathematical programming. Following the arguments by Antle (1983) and Chambers \& Quiggin $(2001,2002)$ in favour of linear utility functions, the Syrian wheat farmers are assumed to be risk neutral and hence a linear objective function which maximizes profit has been used. The above yield response function along with input costs and wheat prices form the set of constraints under which the farm is optimized.

\section{Data}

Syria's Zones 1 and 2 were purposely chosen for this study for their relatively high share in total rainfed wheat land in the country and also their tremendous scope for SI. From among the total of 14 governorates in the country, 12 have areas which fall in Zones 1 and 2, out of which the top three wheat producing governorates (Aleppo, Deraa, and Al-Hassakeh) were included in this study. These three governorates account for about $66 \%$ of total wheat land and $61 \%$ of total wheat production in the country.

A stratified sampling procedure was used to select a total of 461 wheat farms. Proportional samples of 218 and 243 were randomly drawn from 13 villages each from Zones 1 and 2, respectively. The survey was conducted in February-March 2010, where data was collected for the previous calendar year (2009). Tables 1 and 2 provide the profile of the sample wheat farms based on irrigation method, amount of irrigation water application and farmers' perception of the bio-physical characteristics of their farms.

\footnotetext{
2 The Cobb-Douglas production function was chosen because of its desirable properties which include: (i) constant returns to scale; (ii) easy aggregation from individual farms to regional or national levels; (iii) marginal product is proportional to average product; and (iv) the growth rate of output is a linear function of the growth rates of all inputs.
} 
Table 1. Profile of the sample farm households in terms of irrigation method and water use.

\begin{tabular}{|c|c|c|c|}
\hline & Zone 1 & Zone 2 & Total \\
\hline & \multicolumn{3}{|c|}{ Traditional surface canal irrigation (TI) } \\
\hline Farms using canals $(\%)$ & 37.6 & 78.2 & 59 \\
\hline Average water used (m³/ha) & 2,554 & 2,744 & 2,686 \\
\hline \multirow[t]{2}{*}{ Average yield (kg/ha) } & 5,384 & 4,892 & 5,040 \\
\hline & \multicolumn{3}{|c|}{ Sprinkler irrigation } \\
\hline Farms using sprinklers (\%) & 62.4 & 21.8 & 41 \\
\hline Average water used ( $\left.\mathrm{m}^{3} / \mathrm{ha}\right)$ & 1,852 & 1,910 & 1,869 \\
\hline Average yield (kg/ha) & 5,840 & 5,460 & 5,733 \\
\hline
\end{tabular}

Note: Some farms which use a surface canal apply less than $1,800 \mathrm{~m}^{3} / \mathrm{ha}$, while some farmers who use sprinklers apply excessive irrigation water $\left(>1,800 \mathrm{~m}^{3} / \mathrm{ha}\right)$.

Table 2. Characterization of sample farmlands based on farmers' subjective judgement.

\begin{tabular}{llr}
\hline Attribute & Measurement/scale & $\%$ \\
\hline Depth of well & $0-30$ meters & 41.6 \\
& $31-50$ meters & 52.5 \\
& $51-100$ meters & 5.6 \\
& $100-200$ meters & 0.3 \\
& Over 200 meters & 87.5 \\
Well water salinity* & Low & 12.5 \\
& High & 10.9 \\
Soil type & Shallow & 89.1 \\
& Deep red & \\
\hline
\end{tabular}

*Farmers were asked if they could use the well water for brewing tea. If they responded yes, it was understood to mean the water has low salinity; if no, it was considered to be saline.

\section{Results and discussion}

\subsection{Estimation and valuation of the amount of water conserved}

A potential increase in water demand due to cost savings and higher water productivity of ISI relative to TSI may possibly counter the objective of irrigation water conservation. However, this threat is nonexistent in the case of Syrian wheat farms for two reasons:

(i) there are no suitable lands for agricultural expansion in the Syria's wheat producing areas (Zones 1 and 2) and hence no additional demand for irrigation water is expected from new wheat land coming into cultivation; and

(ii) currently, there are no wheat farms in Syria which are purely rain-fed: hence, the introduction of ISI will not expand the irrigated wheat land and therefore the total demand for irrigation water is not expected to increase as a result. 
Table 3. Coefficient estimates of the yield response function.

\begin{tabular}{lcc}
\hline Inputs/attributes & B & Std Error \\
\hline Constant) & 5.25 & $0.81 * * *$ \\
Area (ha) & 0.01 & 0.01 \\
Quantity of irrigation water $\left(\mathrm{m}^{3} / \mathrm{ha}\right)$ & 0.14 & $0.03 * * *$ \\
$\mathrm{~N}(\mathrm{~kg} / \mathrm{ha})$ & 0.11 & $0.02 * * *$ \\
$\mathrm{P}(\mathrm{kg} / \mathrm{ha})$ & 0.07 & $0.02 * * *$ \\
Seed $(\mathrm{kg} / \mathrm{ha})$ & 0.12 & $0.03 * * *$ \\
Zone dummy & -0.06 & $0.03 *$ \\
Soil salinity dummy & -0.04 & 0.03 \\
Soil type dummy & 0.01 & 0.03 \\
Wheat variety dummy & 0.03 & 0.02 \\
Irrigation Method dummy & 0.13 & $0.02 * * *$ \\
years of schooling & 0.04 & $0.01 * *$ \\
Rain fall & 0.08 & 0.09 \\
$R^{2}$ & 0.67 & \\
\hline
\end{tabular}

*The dependent variable is the natural logarithm of yield $(\mathrm{kg} / \mathrm{ha})$. All explanatory variables, except the dummy variables, are also in natural logarithms.

From the regression estimates of the yield response function (Equation 1), the average marginal product $(m p)$ of water $^{3}$ is $0.337 \mathrm{~kg} / \mathrm{m}^{3}$ (Table 3). Multiplying the $m p$ of water by the average price of wheat $(20 \mathrm{SYP} / \mathrm{kg})^{4}$, the marginal value product of water is estimated at $6.67 \mathrm{SYP} / \mathrm{m}^{3}$.

Depending on the amount of water applied with TSI, the soil type, slope of the field, rainfall received in that particular year and condition of the drainage structure, all or part of the excess water applied by TSI over ISI is lost due to evaporation and/or consumed by weeds. The amount and value of water conserved will therefore depend on: (i) how the conserved water will be used in the future; and (ii) our assumption about the percentage of the total excess water that is lost by soil and weed canopy evaporation this season or next. For instance, Allen et al. (1998) gave a conservative estimate of $20 \%$ as being lost to evaporation, while CropSyst simulation results and actual measurement carried out by Eberbach \& Pala (2005) for the Tel Hadya area in Syria show that at least $40-50 \%$ of rainwater received is lost by evaporation.

The $m p$ of water varies depending on the type (TSI or ISI) and method (surface or sprinkler) of irrigation. Generally, ISI and sprinklers lead to a higher $m p$ of water than TSI and surface canals. Suppose that the portion of the conserved water will be used by a farmer using TSI with a surface canal, then its new $m p$ will be $0.23 \mathrm{~kg} / \mathrm{m}^{3}$, which is less than $0.25 \mathrm{~kg} / \mathrm{m}^{3}$ (the weighted average of the current $m p$ for TSI with surface canal and TSI with sprinklers from which water is conserved) thereby leading to a loss of value. However, the $m p$ of that portion of the conserved water that would have otherwise been lost to soil and canopy evaporation will increase from 0 (as it would have simply been lost to crop use) to the $m p$ of its new use (for example $0.23 \mathrm{~kg} / \mathrm{m}^{3}$ if used for TSI with a surface canal, or $0.45 \mathrm{~kg} / \mathrm{m}^{3}$ if it is used for ISI with sprinklers). The net effect can either be an increase or decrease in the value of the

\footnotetext{
${ }^{3}$ From the $\log$-linear estimation we have: $\partial \ln ($ yield $) / \partial \ln (Q W)=0.14$. Multiplying the numerator by $\partial($ yield $) / \partial($ yield $)$ and the denominator by $\partial(Q W) / \partial(Q W)$, noting $\partial \ln (y) / \partial \ln (y)=1 / y$ for any $y$ and solving it at the average values of yield and QW results in: $m p=\partial($ yield $) / \partial(Q W)=0.337$.

${ }^{4} 1 \mathrm{US} \$(\mathrm{USD}) \approx 50$ Syrian Pounds (SYP).
} 
conserved water, depending on the percentage of loss to evaporation and the future use of that portion of water that would not have been lost to evaporation. On the other hand, if we suppose that the conserved water will be used at present or in the future by a farmer who is using ISI with a surface canal or sprinklers, then conservation leads to a higher $m p$ of 0.36 or $0.45 \mathrm{~kg} / \mathrm{m}^{3}$, and hence a higher value of the conserved irrigation water (Figure 1).

\subsection{Estimation of economic benefits and costs to adopters}

ISI by design reduces the amount of irrigation water applied as compared to TSI. As a result, there is a reduction in the amount of fuel and other costs associated with pumping. Most of the pumps in Syria use diesel fuel. The sample average depth of the irrigation wells is about $70 \mathrm{~m}$. The average amount of diesel required to pump $1 \mathrm{~m}^{3}$ of water from this depth is 0.41 litres. Multiplying 0.41 litres by the total amount of extra water pumped under TSI over that of ISI in wheat production $\left(1,110 \mathrm{~m}^{3} /\right.$ ha/year or 120.9 million $\mathrm{m}^{3}$ per year at the current ISI adoption rate of $22.34 \%$ in the three provinces), we find the estimated amount of diesel saved due to the adoption of ISI to be 49.8 million litres/year. Using an average diesel price of about US\$0.4/litre, the estimated value of diesel saved from the use of ISI in wheat fields is about US\$183/ha, or about US\$19.94 million per year in all three provinces.

In comparison to the base case (TSI using an open surface canal with an application rate of $277 \mathrm{~mm} /$ ha), the adoption of ISI and sprinklers with the current application rate of $146 \mathrm{~mm} / \mathrm{ha}$, leads to a yield gain of about $37 \mathrm{~kg} / \mathrm{ha}$. At the current average wheat price of US $\$ 0.4 / \mathrm{kg}$, a shift from TSI with canals to ISI with sprinklers would lead to a gain in revenue of only about US $\$ 14.74 /$ ha/year. However, this shift leads to diesel savings of about US\$187.84/ha/year. Considering all other costs and benefits, the net effect of the shift from TSI with canals to ISI using sprinklers for the average farmer is a gain in annual profit of about US $\$ 224.38 /$ ha. The total profit gained by all farmers who simultaneously adopted

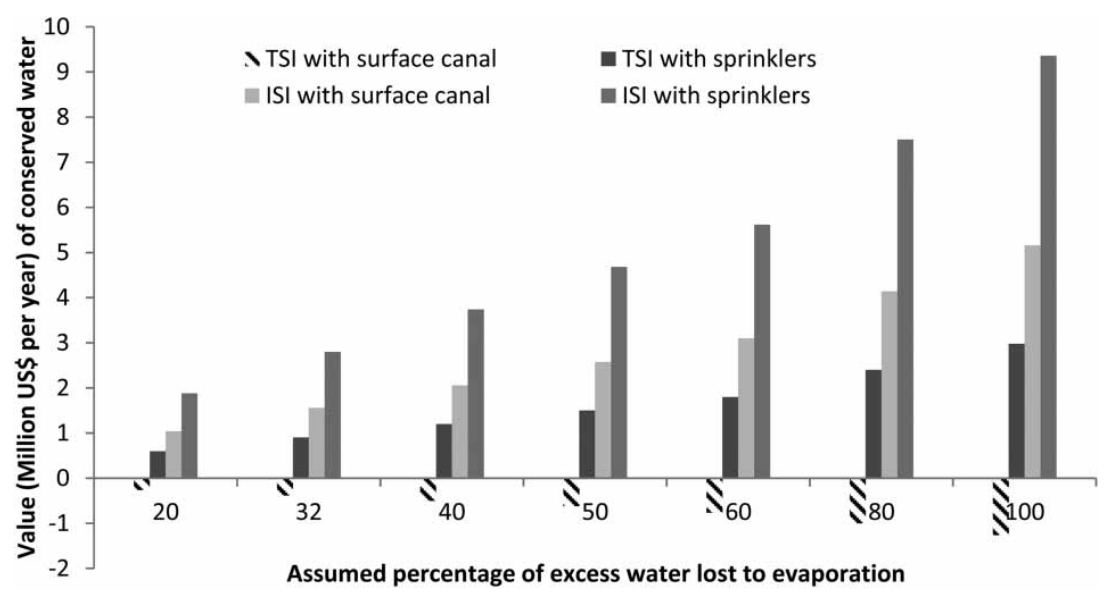

Fig. 1. Economic valuation of irrigation water conservation for different levels of loss due to Evaporation (Million US\$ per year). Note: The figures were computed relative to the weighted average of TSI with canal and TSI with sprinklers; as we can not be sure when the conserved water will be used, and to avoid issues of time preference and hence choice of discount factors, we have compared alternative uses in the same period. 
Table 4. The economic benefits (costs) of the shift from TSI to different irrigation methods.

\begin{tabular}{|c|c|c|}
\hline Item of comparison relative to TSI & $\begin{array}{l}\text { ISI with } \\
\text { sprinklers }\end{array}$ & $\begin{array}{l}\text { ISI with surface } \\
\text { canal }\end{array}$ \\
\hline Yield (kg/ha) gain or loss & 37 & -456 \\
\hline Value of yield gain or loss (US\$/ha) & 14.74 & -182.32 \\
\hline Value of diesel saved (US\$/ha) & 187.84 & 162.10 \\
\hline Saving from other inputs (labour, maintenance, depreciation ...) in US $\$ /$ ha & 21.80 & 24.00 \\
\hline Profit (loss) due to the adoption of ISI (US\$/ha/year) & 224.38 & 3.78 \\
\hline $\begin{array}{l}\text { National benefit at current level of adoption of ISI in the three provinces } \\
\text { (million US\$/year) }\end{array}$ & 4.46 & 0.02 \\
\hline Percentage of adopters & 18 & 4 \\
\hline $\begin{array}{l}\text { Total national benefit due to the adoption of ISI in the three provinces } \\
\text { (million US\$/year) }\end{array}$ & 4.48 & \\
\hline
\end{tabular}

Note: a unit cost of US\$50 and life time of 20 years was assumed for sprinklers; the typical adopter has 35 sprinklers to irrigate an average of 6 hectares of wheat.

both ISI and sprinklers (18\% of total) in the three provinces studied is estimated at about US\$4.48 million per year (Table 4).

The farmers who shifted from TSI with open canals to ISI with open canals, on the other hand, suffered a yield loss worth US\$182.32/ha. However, they used less diesel to pump water, from which they saved US\$162.1/ha. Considering all other cost savings from the shift, the net effect is that they received an extra profit of only about US\$3.78/ha. The total benefit of the shift from TSI with surface canal to ISI with surface canal for all such farmers (4\% in the three regions) is only about US\$17,000/year.

In summary, depending on (i) the assumption made about the proportion of the excess water applied in TSI which, if not conserved, would be lost to evaporation, (ii) the alternative use of the conserved water, and (iii) assuming that all ISI users were TSI users, the total national impact (farm profits plus value added to the conserved water) of the shift to ISI at its current adoption level of $22.34 \%$ is estimated in the range of US\$1.04-13.82 million per year. The only exception which would lead to a negative net national impact (ranging between US\$0.26-1.26 million per year) is the very unlikely situation where all the conserved water is used for TSI.

It is also worth noting that water conservation has other environmental benefits, such as the prevention of desertification, which are not included in this analysis. The benefits to ISI are even more pronounced when it is coupled with sprinklers, which are adopted by $41 \%$ of the farmers. Assuming that the current users of either or both ISI and sprinklers were users of TSI and for assumed evaporation rates ranging between 20-100\%, the combined effect of the introduction of ISI and sprinklers in 2010 was between US\$0.54 million and US\$2.68 million.

\subsection{A policy option for enhancing groundwater conservation}

The results in Section 5.1 show that the shift from TSI to ISI makes a clear contribution towards the overall effort of water conservation in Syria. However, in the three study provinces, TSI is still 
Table 5. Breakdown of the current cost of irrigation $\left(\mathrm{US} \$ / \mathrm{m}^{3}\right)$.

\begin{tabular}{llc}
\hline & \multicolumn{2}{l}{ Cost $\left(\mathrm{US} \$ / \mathrm{m}^{3}\right)$ to deliver $1 \mathrm{~m}^{3}$ of water to the field using: } \\
\cline { 2 - 3 } Cost item & Surface canals & Sprinklers \\
\hline Gasoline for pumps* & 0.165 & 0.165 \\
Labour & 0.018 & 0.015 \\
Depreciation of sprinklers & 0.000 & 0.008 \\
Lubricant & 0.004 & 0.003 \\
Water user charge $\left(\mathrm{SYP} / \mathrm{m}^{3}\right)$ & 0.000 & 0.000 \\
Total & 0.187 & 0.191 \\
\hline
\end{tabular}

*Note: Gasoline price of US $\$ 0.4 /$ litre and an average of 0.41 litres of gasoline for pumping $1 \mathrm{~m}^{3}$ of water were used.

practiced on 0.38 million hectares $(78 \%)$ of wheat farms with an average irrigation water application rate of $2,600 \mathrm{~m}^{3} /$ ha. The question is then: what can the government do to encourage the adoption of ISI? We hypothesize that the introduction of a policy to penalize farmers applying above the recommended amount of irrigation water could do the job. To this effect, using current production technology and at the current average levels of the other inputs, the profit ${ }^{5}$ maximizing levels of irrigation water application under different scenarios can be solved using the parameter estimates of the production function provided in Table 3. Based on the breakdown of the cost of irrigation water used in this analysis provided in Table 5, the optimality conditions are drawn by equating the marginal value product of water and its unit cost.

Under the existing conditions where farmers do not pay any water user charges, we find that the profit maximizing application rate for surface canal and sprinkler users are 1,190 and 1,348 $\mathrm{m}^{3} / \mathrm{ha}$, which are 56 and $28 \%$ lower than the current averages of 2,686 and $1,870 \mathrm{~m}^{3} / \mathrm{ha}$, respectively. The weighted average of the optimal application rates for both sprinkler and open canal users is $1,255 \mathrm{~m}^{3} / \mathrm{h}$, which is $46 \%$ lower than the weighted average of current application rates $\left(2,349 \mathrm{~m}^{3} / \mathrm{ha}\right)$, showing a general over-irrigation in the study areas. Results based on the CropSyst simulation for the Tel Hadya area in Syria also found that the biophysically optimal SI water application rate is $134 \mathrm{~mm}$ (Sommer et al. 2011), which is very close to our findings. The officially recommended levels of irrigation water application in Syria's Zones 1 and 2 are between 600 and $1,800 \mathrm{~m}^{3}$ (or $60-180 \mathrm{~mm}$ ). Thus, apparently, farmers are unnecessarily applying too much irrigation water.

There are at least three possible explanations for over-irrigation

(i) the wheat farms in Syria are purely commercial, producing for the market and, as farm businesses, their objective is to maximize profit. However, given the complexity of the farm business and the typical Syrian farmer's lack of proper books of accounts, they might be

\footnotetext{
${ }^{5}$ Profit here refers to total revenue minus cost of irrigation water. The standard utility maximization is used here, where farmers are assumed to be risk neutral and hence have linear utility function. The objective of the typical farmer under these sets of assumptions is therefore to maximize the utility of profit by choosing the level of irrigation water application while keeping all other inputs at their current average values.
} 
trying to achieve their profit maximization goal by maximizing yield (while failing to ensure cost efficiency) and hence irrigate beyond the economically optimal level;

(ii) following common practice, Syrian farmers apply up to $100 \mathrm{~mm}$ per single irrigation (more than actually required) and are anxious about delayed rains and irrigate the dry land at planting and only two to three more times later. Irrigation might then take place earlier than necessary (because of time, labour or equipment constraints) with a high chance of irrigation being followed by rain that potentially could have substituted a significant part of the irrigation water applied;

(iii) farmers are not paying for water use and hence the loss from excessive pumping (US\$279.44/ha) is not high or obvious enough to them to lead to prudence.

We argue that a policy that introduces a PEAIW would force farmers to reduce their application rates. The overarching questions then become: how will such a policy affect farm profits, and what are the overall economic and environmental impacts of such a policy? To be able to answer these questions, the response of the profit maximizing typical farmer are simulated under different levels of assumed percentages of water losses to evaporation and at a PEAIW of US $\$ 1 / \mathrm{m}^{3}$, which is high enough to ensure all farm types use less than or equal to the maximum allowable amount of irrigation water. Our simulations results show that a prohibitively high penalty (say US $\$ 1 / \mathrm{m}^{3}$ ) for applying more than $1,800 \mathrm{~m}^{3}$ of irrigation water per ha (the upper bound of the government recommendation) reduce the application rate of the typical farmer to the recommended level. Model results also show that the policy would not affect the current ISI adopters using both surface canal and sprinklers, whose application rates are within the recommended range $^{6}$. An even lower maximum allowable application rate of $1,350 \mathrm{~m}^{3} /$ ha (the application level which leads to the highest simulated profit) coupled with a policy that introduces very high PEAIW (which would affect only those exceeding the limits) would lead to more prudent use of water by all farmers, thereby leading to an annual conservation of $78-378$ million $\mathrm{m}^{3}$ of groundwater (Figures 2(a)-2(c)). These results show that it is possible for the government to curtail the high application of irrigation water, and hence achieve higher efficiency of irrigation water and some level of groundwater conservation in the face of rapid depletion of this resource in Syria.

The results in Figures 2(a)-2(c) show that introducing PEAIW will not only increase the efficiency of use and conserve the scarce groundwater resources but also lead to sizeable farm-level economic benefits, especially for those using ISI. The beauty of such a policy is that even the farmers who are using TSI with a surface canal will not suffer any economic loss. What is more interesting is that the simulated profit maximizing level of irrigation water application which is closer to the lower bound of the official recommendation leads to the highest level of economic benefits to farmers with substantial amount of water conservation. Analysis of the effects of applying PEAIW in the three regions with maximum allowable rates of 1,800 and $1,350 \mathrm{~m}^{3}$ shows that under the current adoption rates of ISI and sprinklers, the policy will lead to losses in total national wheat supply of $4 \%$ and $6 \%$. However, the supply loss can be reversed if the policy succeeds in increasing the adoption rate of

\footnotetext{
${ }^{6} \mathrm{We}$ assume that there is no, and will not be, a market for irrigation water licenses.
} 

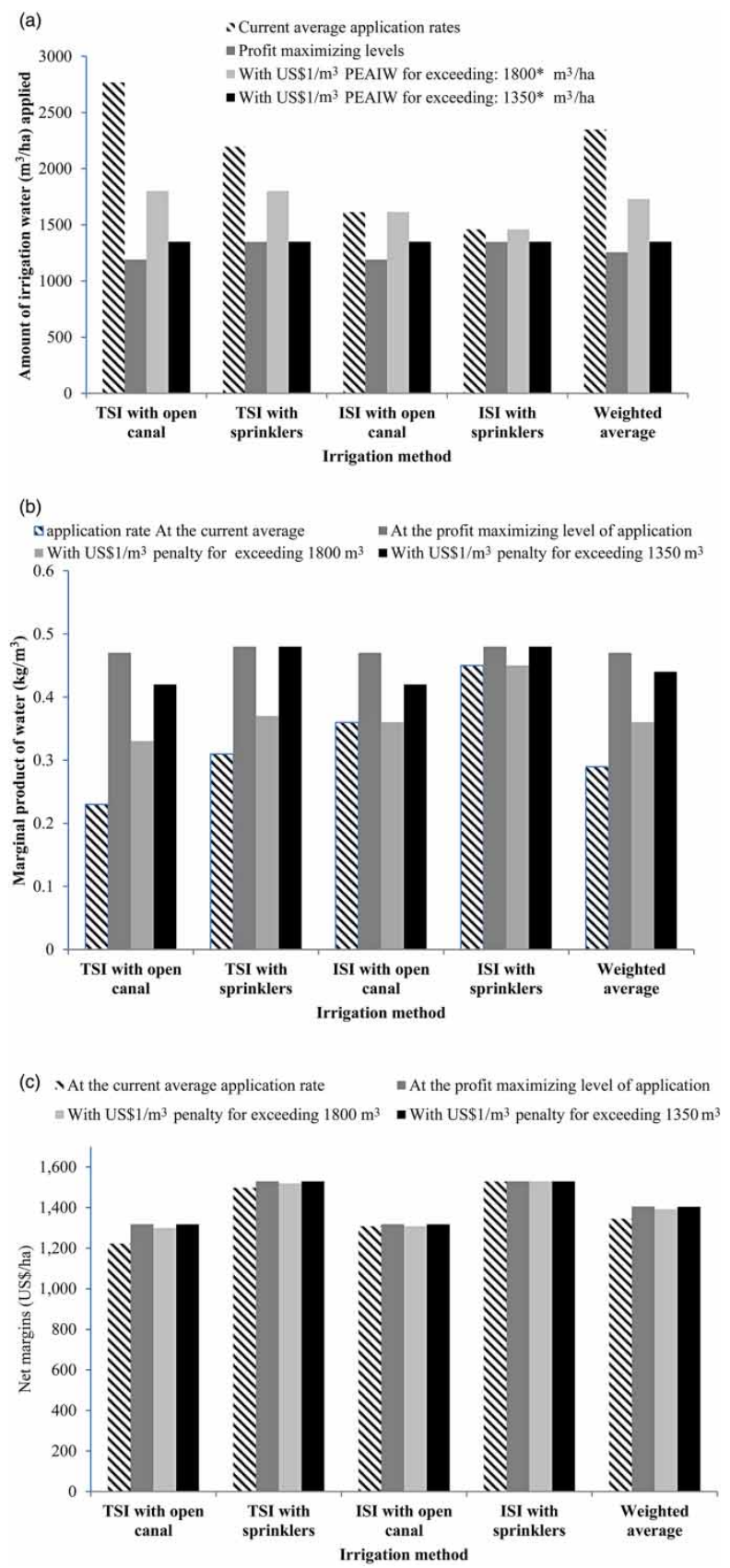

Fig. 2. (a) Farm level impacts of PEAIW on the amount of irrigation water applied. Note: $1,800 \mathrm{~m}^{3} / \mathrm{ha}$ is the upper bound of the officially recommended level of irrigation water; $1,350 \mathrm{~m}^{3} / \mathrm{ha}$ is the highest simulated profit maximizing irrigation water application rate and is selected as a cut-off point for ease of imposing a uniform policy for all farmers, which makes the implementation of the policy relatively easier. There could be many ways of implementing the policy and applying the penalty, but installing meters for all wells could be one option. (b) Farm level impacts of PEAIW on the marginal product of water. (c) Farm level impacts of PEAIW on net margins (US\$/ha). 
sprinklers from the current $41 \%$ to above 78 and $94 \%$, under the 1,800 and $1,350 \mathrm{~m}^{3} / \mathrm{ha}$ cut-off points, respectively.

\section{Conclusions}

An international conference on policies for water and food security in the dry areas was held in Cairo, Egypt, from 24- 26 June 2013. The conference was attended by ministers of agriculture from at least five countries, by policymakers, scientists and experts from more than 20 countries, and by the Consultative Group for International Agricultural Research - comprised of 15 international agricultural research centres distributed around the globe. Valuation of water was one of the most important issues which came out strongly as an important step towards food and water security in the dry areas. Given the urgency of measures needed to conserve groundwater, which is depleting fast (for example up to 6 meters per year in some parts of Syria), the issue of water valuation as a vehicle of conservation in the dry areas is no more one of whether or not, but rather one of how.

Agriculture is the main stay of a large number of people in the dry areas. As a result, policies that have, or are perceived to have, adverse effects on food prices are not well received and have historically been followed by major uprisings in the developing world. As a result, despite the trend of depletion of water resources and clear evidence of misuse of irrigation water by many farmers, governments in the dry areas have been avoiding the idea of water pricing (better termed as 'water valuation'). This stance by many governments is mainly based on the assumption that policies that aim at valuing water will necessarily have negative effects on farmers. Given such overall understanding and belief, governments might face substantial challenges to introduce policies for pricing every cubic meter of water used. This is even more the case when the level of awareness about the seriousness of the depletion of groundwater resources among farmers is low. The fact that many farmers believe that any lower application rate of irrigation water than their current high (not to them) level would necessarily lead to reduced yield and/or farm profits.

This paper appreciates the challenges faced by farmers and policymakers, and argues that designing a strategy that will achieve some level of conservation while also creating the needed awareness among farmers is a good place to start. Hence, it is argued here that a policy that does not affect farmers who are making reasonable use of water but penalizes those who abuse it can be received relatively well and lead to some level of groundwater conservation. Particularly, this paper proposes that the countries in the dry areas can safely use a policy that introduces PEAIW as a vehicle to make farmers aware of the problem and hence aware of the need for being prudent in their water use, which will also lead to conservation of sizeable amount of groundwater. Using a case study from Syria and applying a simple optimization model, this paper has demonstrated that such a policy would compel farmers to adopt water saving technologies, such as sprinklers and ISI techniques. By so doing, the policy not only leads to groundwater conservation but also to a Pareto optimal condition where benefits are distributed in such a way that nobody experiences loss and at least some or at best all gain.

At its current adoption level of 32\%, the adoption of ISI in Syria has so far led to an average conservation of $418 \mathrm{~m}^{3}$ of irrigation water per hectare per year. The shift from TSI to ISI also has farmlevel economic benefits, regardless of the irrigation technology used. However, ISI leads to the highest farm-level economic benefit (a 25\% increase in farm profits) when jointly adopted with sprinkler technologies. Otherwise, if farmers continue to use open canals, the shift from TSI to ISI leads to a yield loss which offsets most of the fuel cost savings, leading to only a small increase (7\%) in farm profits. 
Model results show that a policy that introduces prohibitively very high PEAIW will make the high application rates under TSI with open canals very expensive, thereby making ISI and sprinklers more attractive to farmers. As a result, PEAIW leads to further conservation of groundwater. For example, the introduction of a PEAIW of US $\$ 1$ for every $1 \mathrm{~m}^{3}$ of irrigation water applied in excess of $1,800 \mathrm{~m}^{3}$ (the upper limit of the recommended application range) can lead to further groundwater conservation of up to $619 \mathrm{~m}^{3} /$ ha per year, which is accompanied with no change, or at best very small gains in farm profits. Likewise, if such a high PEAIW is introduced with a cut-off point of $1,350 \mathrm{~m}^{3} /$ ha (the profit maximizing application level for the best technology combinations), additional groundwater conservation of about $999 \mathrm{~m}^{3} /$ ha per year can be achieved along with no change, or at best very small gains in farm profits. These gains, however, come at marginal losses in total national wheat supply of 4 and $6 \%$ for the $1,800 \mathrm{~m}^{3} / \mathrm{ha}$ and $1,350 \mathrm{~m}^{3} / \mathrm{ha}$ cutoff points, respectively. Simulation results also show that the loss in national wheat supply can be fully reversed if the policy succeeds in increasing the adoption rate of sprinklers from the current $41 \%$ to above 78 and $94 \%$, under the 1,800 and $1,350 \mathrm{~m}^{3} /$ ha cut-off point scenarios, respectively.

Imposing any charges, penalties, quotas or changing the property rights of natural resources traditionally and culturally considered as 'free' is not expected to be easy. In particular, the introduction of any payments for irrigation water could be very sensitive in Syria and other countries in the dry areas, as production highly depends on irrigation. However, where there is a political will from the side of the government, we believe that such changes could be introduced without substantial negative social outcomes. For instance, from 1994 in pre-civil war Syria, the government had successfully implemented protection programmes of common resources in the rangelands. The programme banned barley cultivation in the Badia. which was also followed by a big government project, implemented for over 10 years with high community participation, involving the protection of rare plant species, the plantation of rangelands with shrubs, and the introduction of community managed (as opposed to free) grazing of these areas, which were to be used as forage banks, particularly in drought years. Contrary to the prevailing common perception, the aforementioned project has proved that a strong government desire, together with sufficient awareness building and educational programmes for farmers can make it possible to introduce measures for the conservation of natural resources without inducing social anger. Therefore, in the context of pre-civil war Syria, the introduction of a policy that introduces penalties for excessive water abstraction would have been quite feasible, and its political, social and cultural cost would have been much less than many people may think. The fact that PEAIW only calls for a more prudent use of water without cost implications (and even some gains in profit) for farmers who adhere to the national recommendations, makes its implementation particularly feasible. This analysis therefore provides some evidence that PEAIW could be a policy option for countries in the dry areas to curtail the current high application rates of irrigation water without inducing major social disapproval or unrest.

The development of enforcement mechanisms for PEAIW is beyond the scope of this study. However, it is necessary to emphasize the fact that this paper does not propose PEAIW as a panacea for the problem of overexploitation of groundwater. Instead, the penalty could be an element of a wider programme, involving raising the awareness of farmers and community leaders about past and current trends in groundwater exploitation and depletion, the danger of continuing with current excessive application levels by some farmers, the technical feasibility of achieving higher profit levels with reduced application rates, and the urgency of the need for mitigative measures. Moreover, farmer training in efficient water application methods, water use monitoring with wider use of water meters, the involvement of water user associations, and other policies that make the conservation effort more effective, need to accompany the PEAIW. 
Once farmers and community leaders are aware of the need and urgency of conservation measures, asking them to suggest socially and culturally viable and economically feasible implementation modalities that would be acceptable to all or at least the majority of farmers might be a good strategy to ensure their full support and involvement. For instance, the feasibility of putting water user associations in charge of enforcement, the installation of water meters, and polices to supervise and hold transgressors accountable to their actions all need to be raised for discussion as possible options. It is important to note here that implementation strategies might well be different across different countries depending on the political, social and cultural contexts. For instance, in Syria, PEAIW was expected to accompany the already existing subsidies for the purchase of water saving technologies, such as sprinklers, and the guaranteed high output prices. However, a full analysis and description of the best implementation procedures in Syria and other countries is beyond the scope of this paper. Testing the efficacy of these and many other possible options is now the topic of an ongoing research at ICARDA.

\section{References}

Abedrabboh, R. (2007). Water demand management in Syria. In PlanBlue, UNEP \& CIHEAM (eds), Water Demand Management, Progress and Policies. Proceedings of the 3rd Regional Workshop on Water and Sustainable Development in the Mediterranean held in Zaragoza, 17-21 March 2007, Spain, CIHEAM Annual report, CIHEAM, Paris.

Allen, R. G., Pereira, L. S., Raes, D. \& Smith, M. (1998). Crop evapotranspiration: Guidelines for computing crop water requirements. FAO Irrigation and drainage paper 56, FAO, Rome. M-56 ISBN 92-5-104219-5

Antle, J. M. (1983). Incorporating risk in production analysis. American Journal of Agricultural Economics 65(5), $1099-1106$.

Bartolini, F., Gallerani, V., Raggi, M. \& Viaggi, D. (2010). Water management and irrigated agriculture in Italy: multicriteria analysis of alternative policy scenarios. Water Policy 12, 135-147.

Chambers, R. G. \& Quiggin, J. (2001). Decomposing input adjustments under price and production uncertainty. American Journal of Agricultural Economics 83, 20-34.

Chambers, R. G. \& Quiggin, J. (2002). The state contingent properties of stochastic production functions. American Journal of Agricultural Economics 84, 513-526.

Convery, F. J. (2013). Reflections - Shaping water policy: what does economics have to offer? Review of Environmental Economics and Policy 7(1), 156-174.

Cornish, G., Bosworth, B., Perry, C. \& Burke, J. (2004). Water Charging in Irrigated Agriculture: An Analysis of International Experience. FAO Water Reports 28. FAO, Rome.

Eberbach, P. \& Pala, M. (2005). Crop row spacing and its influence on the partitioning of evapotranspiration by winter-grown wheat in Northern Syria. Plant and Soil 268, 195-208.

Farm Resource Management Program (FRMP) (1991). Annual Report for 1990. International Center for Agricultural Research and the Dry Areas (ICARDA), Aleppo, Syria.

Huffaker, R., Whittlesey, N., Michelsen, A., Taylor, R. \& McGuckin, T. (1998). Evaluating the effectiveness of conservation water-pricing programs. Journal of Agricultural and Resource Economics 23(1), 12-19.

Ilbeyi, A., Ustun, H., Oweis, T., Pala, M. \& Benli, B. (2006). Wheat water productivity in a cool highland environment: effect of early sowing with supplemental irrigation. Agricultural Water Management 82, 399-410.

Lund, A. (1999). The Impacts of irrigated agriculture in the Southwestern United States. Published online. See: http://www. earlham.edu/ biol/desert/irrigation.htm (accessed 19 October 2010).

Michelsen, A., Taylor, R. G., Huffaker, R. G. \& Thomas McGuckin, J. (1999). Emerging agricultural water conservation price incentives. Journal of Agricultural and Resource Economics 24(1), 222-238.

Nova (2006). Salinity: The Awakening Monster from the Deep. Nova: Science in the News. Australian Academy of Sciences, Canbera. See: http://www.science.org.au/nova/075/075key.htm (accessed 11 August 2010).

Oweis, T. (1997). Supplemental Irrigation: A Highly Efficient Water use Practice. ICARDA, Aleppo, Syria.

Oweis, T. \& Hachum, A. (2004). Water harvesting and supplemental irrigation for improved water productivity of dry farming systems in West Asia and North Africa. Agricultural Water Management 80, 57-73. 
Oweis, T. \& Hachum, A. (2009). Optimizing supplemental irrigation: tradeoffs between profitability and sustainability. Agricultural Water Management 96, 511-516.

Oweis, T., Pala, M. \& Ryan, J. (1998). Stabilizing rain-fed wheat yields with supplemental irrigation and nitrogen in a Mediterranean-type climate. Agronomy Journal 90, 672-681.

Oweis, T., Zhang, H. \& Pala, M. (2000). Water use efficiency of rain-fed and irrigated bread wheat in a Mediterranean environment. Agronomy Journal 92, 231-238.

Salkini, A. B. (1992). Impact assessment of supplemental irrigation on rain-fed wheat-based farming systems in Syria. $\mathrm{PhD}$ Thesis, University of Reading, UK.

Sommer, R., Oweis, T. \& Hussein, L. (2011). Can supplemental irrigation alleviate the effect of climate change on wheat production in Mediterranean environments? Oral presentation at: ASA, CSSA, SSSA International Annual Meetings, October 16-19 2011, San Antonio TX, USA. See: http://a-c-s.confex.com/crops/2011am/webprogram/Paper65601.html (accessed 18 April 2012).

Stöckle, C. O., Donatelli, M. \& Nelson, R. (2003). CropSyst, a cropping systems simulation model. European Journal of Agronomy 18, 289-307.

Turner, K., Georgiou, S., Clark, R., Brouwer, R. \& Burke, J. (2004). Economic Valuation of Water Resources in Agriculture: From the Sectoral to A Functional Perspective of Natural Resource Management. FAO, Rome. See: http://www.fao.org/ docrep/007/y5582e/y5582e00.htm (accessed 10 January 2014).

United Nations World Water Assessment Program (UNWWAP) (2012). Managing Water Under Uncertainty and Risk. UNWWAP, Paris. See: http://unesdoc.unesco.org/images/0021/002154/215492e.pdf (accessed 10 January 2014).

World Bank (WB) (2001). Irrigation sector report on Syrian Arab Republic. Report No. 22602-SYR. Rural Development, Water and Environment Group, Middle East and North Africa Regional Program, The World Bank, Washington, DC.

Received 2 September 2013; accepted in revised form 12 December 2013. Available online 31 January 2014 